\title{
Repression Hurts: Coercive Government Responses and the Demise of Terrorist Campaigns.
}

\author{
Ursula E. Daxecker ${ }^{1}$ \\ Colorado State University \\ Michael L. Hess ${ }^{2}$ \\ University of New Mexico
}

\begin{abstract}
The question of how terrorist campaigns end has only recently started to attract scholarly interest. In this paper, we present a cross-national analysis of terrorist group duration that includes information on the characteristics of terrorist groups and the countries in which groups operate. In addition, we develop an argument that expects that the effect of repression on group duration is contingent on countries' regime type. We argue that repression produces a backlash effect in democracies, subsequently lengthening the duration of terrorist organizations. In authoritarian regimes, however, coercive strategies are expected to deter groups' engagement in terrorism, thus reducing the lifespan of terrorist groups. Using data on terrorist groups from the RAND-MIPT database and presented in Jones and Libicki (2008), we find empirical support for the expected effect of repression and democracy on terrorist campaign duration for the 19762006 period. Robustness tests for alternative measures of repression and democracy confirm these results.
\end{abstract}

\footnotetext{
${ }^{1}$ Assistant Professor, Department of Political Science, Colorado State University, ursula.daxecker@ colostate.edu.

${ }^{2}$ Instructor, Department of Political Science, University of New Mexico, MiHess@ salud.unm.edu.
} 
"But then Bloody Sunday happened and again this incredible sense of outrage. . . And following along Bloody Sunday I decided that what I was doing. . . was wanting to go home more and more. And as soon as I came home, I got into Sinn Fein, and it was a natural progression from there. Because my beliefs were fairly well formulated at the time. The British were killing our people, they were locking them up, and they were nothing more than Stormont."

\section{Introduction}

What explains when and why terrorist groups decide to end their campaigns? The factors influencing the duration and termination of terrorist organizations have only recently started to attract the attention of terrorism researchers. In answering the above question, approaches have either focused on whether certain group characteristics are related to the demise of terrorist campaigns, or emphasized the effect of groups' external environment on the lifespan of terrorist groups. In this paper, we develop an argument emphasizing the role of state responses to terrorism and their effect on the probability of terrorist group termination. Specifically, we argue that state repression is a counterproductive strategy that results in backlash and increased duration of terrorist organizations in democratic states, but can contribute to the decline of terrorist groups in non-democratic regimes. In democracies, harsh government responses to terrorism reduce the legitimacy of the regime and may thus contribute to popular support for terrorist organizations. Conversely, the use of coercive strategies is commonplace in authoritarian regimes, thus not altering the perceived legitimacy of the regime. Since information on terrorist organizations almost certainly also influences the probability of survivorship, we include a number of group-level characteristics, such as organization size, ideology, group goals, and foreign support in our empirical analysis.

\footnotetext{
${ }^{3}$ A former IRA member describing his decision to join the organization, as quoted in White (1989: 1292).
} 
The response of the British government to escalating terrorist violence in Northern Ireland in the late 1960s, for example, was characterized by harsh repressive measures. Interventions included internment without trial, criminalization of terrorism suspects, coercive interrogation, curfews and extensive search operations, as well as military deployment (LaFree et al., 2009; Sanchez-Cuenca and de la Calle, 2009). The adoption of repressive counterterrorism policies contributed to distrust in the government among Catholics and resulted in a wave of recruitment for the IRA (White, 1989; LaFree et al., 2009). When gradual changes in British counterterrorism policy from suppression to accommodation took place in the 1980s, Catholics started to believe that acceptable reform of Northern Ireland was possible, opening the door for peace negotiations (Guelke, 2007). A series of cease-fires negotiated with paramilitary forces in the mid-1980s and early 1990s culminated in the Good Friday Accords in 1998.

This example underlines the central dynamic emphasized in this paper. We argue that the use of coercive measures in response to terrorism is counterproductive in democracies. Repressive strategies contradict the values such regimes explicitly subscribe to and can therefore backfire and increase support for terrorist groups. Conversely, repression is frequently used in non-democratic regimes. Harsh responses to terrorist activity will thus not reveal new information on the government's true nature and fail to increase group support. In consequence, coercive strategies can lengthen the lifespan of terrorist organizations in democratic regimes, but the opposite effect occurs in non-democracies.

This research is significant for several reasons. First, the argument reconciles contradictory predictions with regard to the effect of repression on terrorist group duration. We argue that existing studies have produced inconsistent findings for two reasons. First, most evidence comes from studies of a small number of cases, thus making it difficult to generalize 
from their findings. ${ }^{4}$ Second, these studies have neglected to highlight the role of regime type and how it could influence the effect of repression on group duration. As outlined above, we expect that the use of repression is counterproductive in democracies, but contributes to the decline of terrorist groups in non-democratic regimes. Second, we conduct a cross-national analysis of terrorist groups that includes data on both group- and state-level characteristics, thus improving earlier studies lacking information on the groups involved in terrorism (Blomberg et al., 2009). Third, this research considers both domestic and international terrorism. Large-N analyses of terrorism focus predominantly on international terrorism yet as Sanchez-Cuenca and de la Calle (2009: 37) point out, the "default option for an insurgent group would seem to be domestic."

The paper proceeds as follows. We first review existing research on terrorist group duration and termination. The next section develops our theoretical argument, which expects that the effect of repression on group termination is conditional on states' regime type. The argument is tested using data on terrorist groups provided in Jones and Libicki (2008). Results show strong support for our expectations. A conclusion addresses implications for future research and policymaking.

\section{The Duration and Termination of Terrorist Groups}

While research has significantly increased our understanding of the formation and recruitment of terrorist groups, dynamics explaining terrorist attacks and target selection, and state responses to terrorism, scholars have only recently started to pay attention to the question of why and how terrorist campaigns end. Despite some early work emphasizing the need to address

\footnotetext{
${ }^{4}$ The two large- $\mathrm{N}$ analyses of terrorist group duration we are aware of do not include measures for repression (Blomberg et al., 2009; Jones and Libicki, 2008).
} 
terrorist group duration and termination, case study assessments of particular groups dominated research on the subject until a recent rise in systematic investigations. ${ }^{5}$ One strand of research evaluates explanations that analyze how the characteristics of terrorist groups are related to group disengagement. ${ }^{6}$ Existing work on group-level characteristics and terrorism decline has emphasized the importance of group ideology, group strength, the breadth of goals pursued, and group cohesion. Major findings with regard to group-level explanations show that religious and nationalist groups have longer durations than leftist or right-wing organizations (Hoffman, 2006). In addition, group strength, measured as the size of terrorist groups, has been shown to increase the lifespan of terrorist groups (Jones and Libicki, 2008). No clear findings have emerged with regard to the breadth of terrorist goals (Jones and Libicki, 2008). Finally, the importance of group cohesion has not been analyzed outside a case study framework, likely stemming from the fact that the operationalization of this concept for large-N research seems prohibitive and that group cohesion may be endogenous to decisions to disengage from a terrorist organization.

A second strand in the literature emphasizes the relevance of state characteristics and state responses for explaining the duration and termination of terrorist groups. Explanations have stressed the importance of economic wealth, country size, regime type, and repression. With regard to economic wealth, empirical research has either found no relationship between wealth

\footnotetext{
${ }^{5}$ Blomberg et al. (2009) and Jones and Libicki (2008) provide large-N analyses of the determinants of terrorist group termination. However, despite Blomberg et al.'s (2009) focus on terrorist groups, they do not include any group characteristics in their empirical analysis. Jones and Libicki's (2008) study is a major contribution for its inclusion of a variety of group-level characteristics. Yet their findings may be biased because their empirical analysis includes only groups that ended their campaigns within their time frame, leaving out organizations that continued their campaigns beyond 2006 (Jones and Libicki, 2008: 19). In addition, the authors present mostly descriptive statistics and do not employ sophisticated regression models to test their hypotheses.

${ }^{6}$ The importance of explanations emphasizing group characteristics and dynamics at the grouplevel is evident when trying to understand why groups disengage from terrorism. Although macro-level conditions such as wealth or democracy can be useful to understand terrorism's decline by focusing on structural constraints affecting terrorist organizations, they neglect the decision-making capacity of sub-state actors. While we do not propose a group-level explanation of terrorist group duration, our empirical analysis controls for a variety of group characteristics.
} 
and group termination (Jones and Libicki, 2008) or found a positive relationship, indicating that groups operating in countries with higher income levels are more likely to survive (Blomberg et al., 2009). Population size is found to increase the duration of terrorist groups in Blomberg et al. (2009). Since the theoretical argument in this paper highlights the effect of repression and regime type, explanations focusing on these concepts will be discussed in more detail below.

Much research on regime type in the literature on terrorism and insurgency centers on whether democracies are more likely to be the targets of terrorist or insurgent activity and have greater difficulties combating violent groups (Eubank and Weinberg, 1994; Kydd and Walter, 2006; Pape, 2005; Li, 2005; Fearon and Laitin, 2003; Gurr, 1971). This research can be useful when it comes to analyzing the duration of terrorist campaigns, but offers contradictory expectations. Some argue that since democracy is associated with less discrimination and repression and grants citizens civil rights and liberties, it should be associated with lower grievances and fewer incentives to rebel (Li, 2005; Gurr, 1971; Fearon and Laitin, 2003). According to this logic, terrorist groups should be more likely to end their struggle in democratic states. However, others claim that democratic systems place significant constraints on the ability of the state to respond to terrorist activity, giving authoritarian regimes an advantage in the application of counterterrorist policies (Eubank and Weinberg, 1994; Kydd and Walter, 2006; Pape, 2005). This advantage, in consequence, could translate into shorter duration of terrorist campaigns in authoritarian regimes. Empirical research on the relationship between regime type and terrorism duration has not helped settle this contradiction. Blomberg et al.'s (2009) analysis of transnational terrorist organizations does not show a clear relationship between groups operating in democratic countries and group termination. Some of the authors' models suggest that democracy increases the duration of terrorist groups, whereas others show that it reduces the 
lifespan of such organizations. In addition, Jones and Libicki (2008) do not find a significant relationship between democracy and group termination.

Most relevant for the argument put forward in this paper is research that evaluates the role of government responses to terrorist activity and how different strategies affect group termination (Crenshaw, 1991; Della Porta, 2009; Rashwan, 2009; Parker, 2007; Bueno de Mesquita and Dickson, 2007). Research in this area analyzes repression, accommodation, or both and investigates the effect of these responses on terrorist group duration. However, contradictory expectations and evidence exist on the success of the respective strategies. As Crenshaw points out, some research expects that "terrorism would end if governments consistently adopted hardline policies and coordinated their international implementation" (1991: 73). Yet others claim that hard-line policies only encourage terrorism. According to this logic, governments would "become the victims of their own stereotype of terrorism as responsive only to force" (Crenshaw, 1991: 74). In fact, arguments presented in Mason and Krane (1989), Rosendorff and Sandler (2004), and Bueno de Mesquita and Dickson (2007) suggest that groups may engage in violent activity to strategically exploit repressive counterterrorist policies as a way to mobilize popular support.

Anecdotal evidence from case studies of terrorist groups in Northern Ireland, Italy, Germany, and Israel seemingly confirm the latter argument. In a case study of leftist terrorist groups in Italy, Della Porta (2009) finds that repressive policies in Italy turned out to be counterproductive, radicalizing individuals and increasing popular support for the terrorist group. She shows that once policy changed to more accommodative strategies and facilitated departure from the group, the terrorist movement weakened. Similarly, Parker's (2007) comparative case 
study of repression on terrorist activity in five democratic states shows that excessive repression produced more resilient and aggressive groups.

Yet in contrast to findings that repression exacerbates the growth and intensity of terrorism stand studies that present repression as a successful strategy against terrorist groups. Rashwan (2009), for example, argues that the success of the Egyptian government in eradicating two Islamist militant groups can be attributed to the country's strict military security policy. While the policy included excesses and human rights abuses, it inflicted great human losses on both groups, resulting in arrests, deaths, and stiff sentences that ultimately convinced the leadership of defeat. The hard-line policies pursued by Latin American regimes in Uruguay and Argentina provide further support for the success of repression against terrorist groups. The Tupamaros, a leftist guerilla organization that first emerged in Uruguay in the 1960s, were defeated in an all-out war by the army in 1972. Using the power of decree, the military carried out mass arrests and torture and succeeded in breaking the back of the movement (Handelman, 1981). The Argentinian guerilla group Montoneros was eliminated in a brutal counterinsurgency campaign carried out by Videla's dictatorship in the late 1970s, relying on mass arrests, torture, and executions without trial to stifle the group (Lewis, 2006: 209-231). Finally, a statistical study of the relationship between repression and the incidence of terrorist attacks in 37 Muslim states by Testas (2004) shows that higher levels of repression decrease terrorist activity. ${ }^{7}$

In addition, the literature on human rights violations and terrorist incidence is relevant for research evaluating the effect of repression and terrorist group duration. Some research in the literature on human rights and terrorist activity finds a curvilinear relationship between respect

\footnotetext{
${ }^{7}$ Caution is warranted with regard to the comparability of this study to an analysis of duration. First, the dependent variable in Testas' (2004) study is the incidence of terrorist attacks, not duration. Moreover, the author measures repression with data from Freedom House, which may approximate some of the concept at hand, but is typically used to measure democracy.
} 
for human rights and terrorism (Abadie, 2006; Kurrild-Klitgaard et al., 2006). However, Abrahms (2007) and Walsh and Piazza (2010) conclude that respect for human rights reduces terrorism. Walsh and Piazza's (2010) study - arguably the most comprehensive study of the relationship to date - argues that violations of citizens' physical integrity rights (such as disappearances, extrajudicial killings, political imprisonment, and torture) threaten the government's support in the community, in society in general, and internationally. Using a variety of data sources on domestic and international terrorist events, Walsh and Piazza (2010) find that respect for physical integrity rights uniformly reduces the probability of terrorist attacks. While the authors control for the level of democracy by including measures for participation and executive constraints, they do not evaluate whether the effect of repression on terrorist events is contingent on regime type. Finally, a quantitative analysis of terrorist events in Northern Ireland finds that coercive government actions are more likely to result in backlash effects, meaning that they increase the future incidence of terrorism (LaFree et al., 2009).

A final area of research relevant for this paper is the expansive literature on repression and dissent. Similarly to research on repression and terrorist group termination, however, findings have been mixed. ${ }^{8}$ Research has found that repression increases dissent (Francisco, 1995; Mason and Krane, 1989), that repression reduces dissent (Hibbs, 1973), that the relationship is curvilinear (Mueller, 1985), that there is no relationship (Gurr and Moore, 1997), or that dissident groups will substitute violent protest for nonviolent protest depending on the state's use of repression (Lichbach, 1987; Moore, 1998).

\footnotetext{
${ }^{8}$ Research on repression and dissent can be divided into three groups, one of which analyzes how repression influences dissent, a second group that investigates how dissent influences repression, and a third group that acknowledges that repression and dissent are interrelated (see Davenport 2007 for an overview). Since we are interested in the effect of repression on terrorist group duration, we focus on research in the first category. However, it is important to acknowledge that the relationship between repression and group duration could be endogenous, meaning that the duration of terrorist groups could influence government decisions on repression in addition to the relationship evaluated here.
} 
A review of existing research on repression and its effect on terrorist group duration shows that both theoretical arguments and empirical evidence on the relationship are contradictory. One line of reasoning suggests that repression has counterproductive effects on duration because repressive policies increase mobilization and public support for the group (Rosendorff and Sandler, 2004; Bueno de Mesquita and Dickson, 2007). However, a second line of reasoning expects that repression can be a successful strategy against terrorist activity and the sustainability of terrorism over time (Testas, 2004; Omelicheva, 2007). Tilly's (2003) work, for example, suggests that in authoritarian regimes, state repression of autonomous political expression will suppress violent activity like terrorism. Expectations and findings on the relationship between repression and terrorist group duration, therefore, are not conclusive. Repression seemingly exacerbates the intensity and duration of terrorist groups in some cases, but contributes to the decline of such groups in others. No systematic analysis of the relationship between repression and terrorist group duration exists to date. None of the few large-N empirical studies on group duration include a variable for repression, thus making it difficult to evaluate contradictory evidence in case studies. The theoretical argument developed in the next section develops hypotheses that help account for these mixed findings. More specifically, we argue that the effect of repression on group duration is conditional on the regime type of host states.

\section{Repression, Regime Type, and Disengagement from Terrorism}

The argument developed here accounts for inconsistencies in existing research by arguing that the effects of government repression on terrorist group termination are contingent on states' regime type. Our argument emphasizes the effect of coercion on the perceived legitimacy of governments. We argue that the importance of legitimacy considerations explains why repression 
leads to backlash effects (i.e., lengthening the duration of terrorist groups) in democracies. Conversely, the absence of legitimacy concerns explains why government coercion produces deterrence effects (i.e., reducing the duration of terrorist groups) in non-democratic regimes. ${ }^{9}$

In democracies, the use of repression undermines the legitimacy of the government and subsequently limits the public's cooperation in counterterrorism efforts as well as reducing the overall level of support for the government. The use of coercive tactics is usually condemned in democratic states, and applying such tactics thus damages the legitimacy of the government and increases support for terrorist groups and their duration. However, since coercive strategies are commonplace in authoritarian regimes, repression is not expected to hurt the reputation of the government, thus deterring the use of terrorism and shortening the lifespan of terrorist organizations.

\section{Repression and Terrorist Group Duration in Democracies}

As outlined above, the theoretical argument expects that the adoption of harsh techniques in response to terrorist events results in backlash effects in democracies. While repressive measures are intended to weaken a terrorist group and compromise its security, such strategies are expected to backfire in regimes that derive their legitimacy from the guarantee of civil rights and liberties. If the government responds to terrorist activity by imposing repressive measures not only affecting the terrorist organization but also the general population, proactive measures may increase popular sympathies for the grievances expressed by terrorist groups and could even further terrorist recruitment. As Rosendorff and Sandler (2004: 658) point out, coercive tactics "may have a downside by creating more grievances in reaction to heavy-handed tactics or unintended collateral damage.” Therefore, elites in democracies - regimes that protect civil rights

\footnotetext{
${ }^{9}$ We borrow the terms backlash effects and deterrence effects from LaFree et al. (2009).
} 
and liberties - may experience backlash effects for using repression, which can foster terrorist group mobilization and duration.

In democracies, the existence of civil rights and liberties is widely accepted. Government responses to terrorism such as holding suspects without charging them, assassinating suspected terrorists, curbing civil freedoms, or imposing retribution on alleged sponsors thus contradict the fundamental values of such societies. Consequently, government crackdowns on extremists and accompanying policies limiting political freedoms and rights undermine the legitimacy of the government and can lead to the rallying of support behind terrorist groups, facilitating terrorist recruitment and the sustainability of groups over time (Mason and Krane, 1989; Bueno de Mesquita and Dickson, 2007; Walsh and Piazza, 2010). Such backlash is particularly likely if counterterrorist measures are not successful in discriminating between supporters of terrorist organizations and innocent citizens. To effectively combat terrorism, governments need the support of the public, yet coercive strategies employed in response to terrorism reduce this support. The section below outlines two mechanisms on how harsh government responses to terrorism can increase the lifespan of terrorist organizations in democracies. ${ }^{10}$

The first mechanism we propose here emphasizes the effect of harsh policies on the cooperation of local communities with government authorities. Effective policing against terrorism is dependent on cooperation from local society. Terrorism is a relatively rare and dispersed form of violence, meaning that government authorities depend on complete, accurate, and well-timed information in their counterterrorism efforts (Posner, 2007; Tyler et al., 2009). However, intrusive government actions in response to terrorist threats can undermine the

\footnotetext{
${ }^{10}$ The argument developed here draws on Walsh and Piazza (2010) who argue that disregard for physical integrity rights reduces support for the government. However, as mentioned above, their study makes no distinction between the effects of harsh government responses in democratic versus non-democratic regimes. Yet the effect of such policies on popular support for the government seems arguably more relevant in regimes that depend on such support.
} 
legitimacy of governments and result in estrangement of local communities from government authorities (Donohue, 2008). Hence, government responses perceived as harsh and excessive can lead individuals to withhold information out of fear of unfair treatment. In a 2009 survey of Muslim Americans in New York City, Tyler et al. (2009) find that the perceived legitimacy of police actions shapes Muslims' attitudes and behaviors related to cooperation in counterterrorism policy. For example, Muslim Americans' willingness to alert the police to threats is "negatively affected by the belief that Muslims are subject to discrimination" (Tyler et al., 2009: 380).

Moreover, since the goal of terrorist groups is to draw attention to their grievances against the state, overreactions by the government can increase popular sympathy for their cause and subsequently spur recruitment for terrorist organizations (LaFree and Ackerman, 2009). Terrorist organizations depend on support from the community, and harsh government responses can increase overall support for the group, the number of potential recruits, and the resources available for terrorist groups (Abrahms, 2007; LaFree and Ackerman, 2009; Walsh and Piazza, 2010). Accounts of the escalation of violence in Northern Ireland in the early 1970s support such a dynamic. Several studies of the conflict emphasize that coercive measures undertaken by the government were a determinant in driving the growth and intensity of the IRA in this period (Sanchez-Cuenca and de la Calle, 2009; LaFree et al., 2009). Repressive actions taken by the British government included internment without trial, coercive interrogation tactics, and the indiscriminate use of live ammunition against Catholic demonstrators. For example, the Bloody Sunday episode in which 14 civilians were killed by British soldiers led to public outrage in the Catholic community and a shift in political loyalty to the Republican cause among many Catholics (Sanchez-Cuenca and de la Calle, 2009: 42). Repressive British action, therefore, reinforced the legitimacy of the Republican cause both inside and outside the group. Similarly, 
Della Porta (2009) highlights how repressive tactics contributed to the resilience of terrorism in Italy. She argues that hard-line policies can produce counterproductive results by "stiffening individuals as regards their own choices and increasing solidarity outside" (Della Porta, 2009: 84). The Israeli response to terrorist activity is widely seen as more aggressive than most modern democracies. As Parker (2007: 163) points out, "techniques employed by Israeli security forces include patently 'repressive' measures such as targeted assassination, property demolition, military incursions, coercive interrogation, and curfews." Moreover, these government tactics have reportedly resulted in a large number of civilian casualties, suggesting that these actions can fuel the cycle of violence by mobilizing new supporters and strengthening the motivation of group members. ${ }^{11}$

The second mechanism we propose focuses on the ability of democratic states to combat terrorism more generally. We expect that harsh government policies, in addition to reducing cooperation from local communities as outlined above, will reduce the overall level of popular support for the government. Democratic leaders are accountable to the public and can be removed from office if their counterterrorism policies are perceived as unnecessarily harsh and excessive. The use of coercive measures undermines the values democratic regimes represent and can thus threaten the survival of leaders. Leadership turnover may result in policy changes in counterterrorism policies which can subsequently reduce the government's ability to combat terrorist groups. While we are not aware of research that systematically evaluates the effect of repression on leadership removal, Iqbal and Zorn's (2006) analysis of leader assassinations

\footnotetext{
${ }^{11}$ These examples of counterproductive results in several democratic states raise the question for why democracies would use repressive strategies in the first place. Research by Bueno de Mesquita (2005) and Kydd and Walter (2006) suggest a possible explanation. The authors argue that democracies may have to resort to more public and less discriminatory practices when engaging in counterterrorism. Democratic governments are under pressure to "do something" in response to terrorist violence, and less visible strategies can create the perception that the government is not protecting the population.
} 
shows that repression increases the risk of assassination in open-selection systems (i.e. democracies) with weak executives. Moreover, being threatened with removal (rather than being actually removed from office) may be just as consequential for counterterrorism policies. The threat of removal from office can reduce the effectiveness of counterterrorism policies since democratic leaders may decide to "change policies midstream" to avert popular criticism (Walsh and Piazza, 2010: 559). In addition, Walsh and Piazza (2010) emphasize how opposition parties will try to gain political capital by criticizing counterterrorism policies, subsequently reducing the resources devoted to counterterrorism.

\section{Repression and Terrorist Group Duration in Non-Democratic Regimes}

The above section outlined how repressive government action undermines the legitimacy of democratic regimes and subsequently reduces support for the government. We will now analyze why coercive government action can successfully deter terrorist recruitment and reduce the viability of terrorist groups in nondemocratic regimes.

The first mechanism emphasized in the section on democracies above focused on how the use of repression reduces the government's legitimacy and subsequently deters public cooperation with government authorities. We do not expect that repression will have similar consequences in non-democratic regimes. Since the use of repression is commonplace in nondemocratic regimes, the legitimacy of governments is already low, and coercive strategies will thus not substantially affect community support for the government's counterterrorism efforts. Research in the criminology literature, for example, argues that colonial legacies of policing characterized by abuse and violent intimidation in Sub-Saharan Africa explain why legitimacy considerations are not relevant when evaluating predictors of public cooperation with the police 
(Tankebe, 2009). ${ }^{12}$ Society's consideration of police abuse as "a fact of life, inevitable, irresistible" thus explains why legitimacy considerations have little relevance in states with histories of police abuse (Tankebe, 2009: 1280). Consequently, non-democratic leaders can be less concerned with the legitimacy of their actions and thus benefit from deterrence effects of their counterterrorism policies.

Egypt's success in eliminating the Islamist terrorist group al-Jama`a al Islamiyya in the late 1990s supports this logic. The eradication of the group is largely credited to the government's coercive strategies. Beginning in the late 1980s, the government of Hosni Mubarak widened its crackdown against Islamic activists. In adopting such measures, the government "did not distinguish between those Islamists who espoused violence and the vast majority who did not," moving against both mainstream and militants (Gerges, 2000: 604). Throughout the 1990s, the Egyptian government disarmed the most violent fringe groups and inflicted heavy losses on al-Jama`a. By the mid-1990s, the group was limited in its ability to carry out large-scale attacks. Al-Jama a announced the end to all combat operations in July 1997, and with the exception of the Luxor massacre carried out by a fringe group in November of that year, has suspended all violence (Rashwan, 2009: 121). Rashwan (2009) also mentions that the government's successful incapacitation of al-Jama`a shook the leadership of another prominent Islamist group, the Egyptian Islamist Jihad. The fact that a significant number of Jihad's members subsequently joined al-Jama'a's peace initiative provides hints that harsh government measures resulted in deterrence effects in the Egyptian case.

In the previous section on democracies, we also discussed how democratic leaders' electoral accountability can undermine their ability to effectively combat terrorism. We believe

\footnotetext{
${ }^{12}$ Tankebe's (2009) study of public cooperation with police does not focus on terrorism, and the empirical analysis is limited to public opinion polls conducted in Ghana. Yet his general point on how historical context influences considerations of legitimacy is quite relevant for this paper.
} 
that leaders of authoritarian regimes are less constrained in their counterterrorism efforts because they have more control over the media and are less dependent on public opinion for remaining in office (Kydd and Walter, 2006; Pape, 2005). In an analysis of Basque terrorism, Shabad and Llera Ramo (1995: 467) argue that authoritarian regimes "are by their very nature far less inhibited by legal and normative constraints from countering the violence directed against them." Authoritarian leaders can thus be less concerned with the public's response to repressive counterterrorism policies or the electoral consequences of such actions. ${ }^{13}$

Taken together, the above discussion suggests that the effect of repression on group duration varies with regime type. Coercive measures in democracies constrain the civil rights and liberties expected by citizens and thus inadvertently increase the resilience of terrorist groups. Conversely, proactive measures are expected to be successful in deterring the use of terrorism and reducing the lifespan of terrorist organizations in non-democratic regimes. These expectations imply the following two hypotheses:

Hypothesis 1: Repression increases the likelihood of terrorist group duration in democracies. Hypothesis 2: Repression decreases the likelihood of terrorist group duration in non-democratic regimes.

\section{Data and Variables}

As outlined in the preceding sections, this study examines the determinants of terrorist group termination. We argue that repression affects the likelihood of group termination, but that this effect is conditional on regime type. More specifically, the argument expects that the use of

\footnotetext{
${ }^{13}$ We are not arguing that non-democratic leaders are completely insulated from public opinion and electoral concerns. However, while elections are now held in the vast majority of countries, they frequently do not allow for actual electoral competition by limiting or prohibiting the participation of opposition candidates, and incumbents often manipulate the electoral process.
} 
repression produces backlash effects in democracies and increases the probability of group duration. Meanwhile, repression can be a successful strategy in increasing the likelihood of group termination in non-democratic regimes. A statistical analysis of 597 terrorist groups in 88 countries for the 1976-2006 period assembled from the RAND-MIPT database shows support for our hypotheses. Coercive measures in democracies do indeed backfire as they lengthen the duration of terrorist organizations. Yet the same effect does not hold for non-democratic regimes, where repression increases the rate of termination. These results are robust to a number of model specification and alternative measures of key independent variables.

One problem when studying terrorism is the difficulty of defining terrorism itself. Terrorism involves a conflict between a group and a state and is a type of asymmetric conflict. Yet what exactly constitutes terrorism, and how does terrorism differ from other types of asymmetric conflict such as insurgencies and guerrilla campaigns? Without an agreed-upon definition, it is difficult to decide which groups can be labeled terrorist groups. Sanchez-Cuenca and de la Calle (2009: 33) cite a 1988 study by Schmid and Jongman that collected over 100 definitions of terrorism. Another difficulty arises with regard to differentiating among different types of terrorism, such as international and domestic terrorism. For example, Robison et al. (2006: 2010) define transnational terrorism as the "premeditated use of extra-normal violence or brutality by subnational groups to obtain a political, religious or ideological objective through the intimidation of a huge audience, usually not involved with the policy making that the terrorists seek to influence." This definition does not actually make a distinction that clearly delineates transnational terrorism from other types of terrorism. Furthermore, Sanchez-Cuenca and de la Calle (2009: 36) point out problems with the definition of international terrorism in the data on transnational terrorist incidents. For example, in the ITERATE data, which are used by the vast 
majority of studies on international terrorism, attacks are considered international if the nationality of the perpetrator differs from that of the victim, if terrorists attack outside national boundaries, and if terrorists of various nationalities act together. Analyzing a sub-sample of the data, Sanchez-Cuenca and de la Calle (2009) find that a significant number of attacks occur in the country of the terrorists. Another prominent data source, the RAND-MIPT database, defines terrorist events as international if terrorists go abroad to strike their targets, select victims or targets that have foreign connections, or attack airlines' personnel or equipment. Taken together, these issues raise questions over the feasibility and desirability of distinguishing between these two types of terrorism.

This paper uses data on terrorist organizations collected by the RAND-MIPT project and presented in Jones and Libicki (2008). ${ }^{14}$ Terrorism is defined as politically motivated violence against non-combatants for the purposes of causing intimidation and fear against a target audience (Jones and Libicki, 2008: 3). The authors specify that groups consist of collections of individuals united together in non-state organizations or entities that use terrorism to achieve their objectives. Such entities must have a command and control structure that allows them, whether they are loosely or tightlyknit, to have a direction and an organizational framework that can guide them. The RAND-MIPT data listed in Jones and Libicki (2008) cover 648 terrorist groups between 1968 and 2006. ${ }^{15}$ The data include terrorist organizations carrying out international incidents before 1998 and organizations carrying out both international and domestic incidents for the 1998-2006 period. We expect that our argument is applicable to

\footnotetext{
${ }^{14}$ Jones and Libicki (2008: 142-186) provide a list of all terrorist organizations and group attributes in their dataset in the appendix. The RAND-MIPT data used to create their list of terrorist groups is available at http://www.rand.org/nsrd/projects/terrorism-incidents.html.

15 Jones and Libicki (2008) include a few terrorist groups in colonies who were active before that country's independence, such as the Armed Revolutionary Action group active in Mozambique. We excluded such groups from the analysis until states achieved independence.
} 
terrorist groups engaging in both domestic and transnational terrorism. The use of harsh coercive measures in democracies is expected to reduce cooperation with government authorities and increase support for the terrorist group, regardless of whether group members attack domestic targets, target foreign nationals within the terrorist group's homeland, or cross borders to carry out attacks. ${ }^{16}$ Data limitations on the repression variable limit our time frame to the 1976-2006 period. Our unit of analysis is the group-year, with the last year of observation being 2006 or earlier if the group terminated prior to that date. The data provided in Jones and Libicki (2008) list information on a number of group characteristics which we append with country-level data described in more detail below.

The dependent variable, Termination, is a dummy variable coded 0 for each year that a particular group was in operation, and 1 for the year in which the group terminated. Groups still active in 2006 are coded as 0 in the last year of observation. The dataset has 5,283 observations for the 1976-2006 time frame. The data contain 597 groups, and 348 groups ended their campaigns within that period. Data on start and end dates of terrorist organizations come from Jones and Libicki (2008). The authors used the following criteria to code the beginning and end of terrorist campaigns:

The start year of a terrorist group was assigned based on first indication that the group existed and was dedicated to the use of violence. The end year of a terrorist group was assigned based on earliest evidence that the group no longer used terrorism to achieve its goals. This may be because security forces captured and killed most of its members, the group reached a peace agreement with the government, its members shifted to nonviolent means to achieve their goals, or its members splintered to join other groups or start new ones. Regardless of the reason, the group did not commit further terrorist attacks under its name (Jones and Libicki, 2008: 5).

\footnotetext{
${ }^{16}$ Moreover, the two categories may not be mutually exclusive, since groups can engage in both domestic and international terrorism. To ensure that the exclusion of groups carrying out only domestic incidents before 1998 does not change the results, we present a model for the 1998-2006 period in table 2. Findings confirm the conditional effect of repression on group duration for the model including groups responsible for domestic and international incidents.
} 
The inclusion of groups that splintered is potentially problematic since such groups may arguably continue to use terrorism. Fortunately, Jones and Libicki (2008) provide information on how organizations end, and we therefore present a model excluding splinter groups in table 2. Findings show that results are similar when campaigns that splintered are excluded from the analysis. Summary statistics for all dependent and independent variables are presented in table 1.

\section{TABLE 1 ABOUT HERE}

The independent variables attempt to capture both group-level characteristics and statelevel characteristics and investigate their effect on terrorist group failure. State characteristics include economic development level, population size, democracy, and repression. Jones and Libicki identify the host country for each terrorist organization, and we collect data on state characteristics for the host country of the terrorist group for all groups and all years. Terrorist group characteristics include the size of the terrorist group, the ideology or belief system of the group, the goals of the group, and the number of foreign countries in which the group has a presence. Since our primary expectation centers on the effect of repression and regime type, we describe key independent variables first.

The first three independent variables are included to analyze whether the theoretical argument is supported empirically. The first variable, Repression, measures the level of repression in states. Data for this variable were obtained from the Political Terror Scale (PTS). ${ }^{17}$ The Political Terror Scale was compiled from U.S. State Department and Amnesty International reports, and the scale takes the average of the Amnesty International and U.S. State Department ratings (Gibney et al., 2008). The variable is coded 1 through 5, ranging from least repressive to

\footnotetext{
$\overline{{ }^{17} \text { Available online at http://www.politicalterrorscale.org/. }}$
} 
most repressive. ${ }^{18}$ As hypothesized, we expect the effect of repression to be conditional on regime type and therefore do not develop expectations with regard to repression's independent effect on group termination. To ensure that results are not unduly influenced by the repression measure, table 2 presents a model using Cingranelli and Richards' (2004) measure on physical integrity rights and an interaction between this measure and democracy. ${ }^{19}$

The second key independent variable, Polity, measures how democratic countries are and is taken from the Polity IV Project data (Marshall and Jaggers, 2009). ${ }^{20}$ The variable is a scale ranging from -10 , indicating that a country is fully authoritarian, to +10 , indicating a country is fully democratic. ${ }^{21}$ As noted earlier, existing literature has found mixed results for democracy's effect on terrorist group duration, and we do not make a prediction on how democracy will affect terrorist group termination independently. In addition, to confirm that empirical findings are not a result of the operationalization of regime type, table 2 presents a model with a dichotomous democracy variable.

It is our main contention that democracy and repression may not have individual effects on terrorist group termination but exert an effect in combination. Regime type, we argue, makes a difference in how effective the use of repression will be against terrorist groups within states. To model this interaction between repression and regime type, we create an interaction variable multiplying the Repression and the Polity variables. We expect that this variable shows that

\footnotetext{
${ }^{18}$ A score of 1 indicates that a country is under a secure rule of law, people are not imprisoned for their views, torture is rare or exceptional, and political murders are extremely rare. Countries that have a limited amount of imprisonment for nonviolent political activity were rated as a 2 . Those with extensive political imprisonment, common executions or political murders and brutality, and unlimited detention for political views receive a score of 3 on the PTS. A rating of 4 indicates that a country violates political and civil rights for a large number of the population, and that murder, disappearances and torture are a common part of life especially for those who interest themselves in politics and ideas. Finally, a rating of 5 indicates that terror has expanded to the entire population of the country and the leaders are not limited in the way they pursue personal or ideological goals.

${ }^{19}$ Data are available at http://ciri.binghamton.edu/.

${ }^{20}$ Data available at http://www.systemicpeace.org/polity/polity4.htm.

${ }^{21}$ Of all countries in the data, $61 \%$ are democracies with polity scores of 6 or higher.
} 
repression decreases the likelihood of terrorist group termination in democracies, but increases the likelihood of terrorist group termination in non-democracies. ${ }^{22}$

Additional variables included in our statistical models control for other group and state characteristics that are likely to affect group termination. Data for all group characteristics come from Jones and Libicki (2008). First, group size has been shown in previous research to affect the likelihood of group termination, with larger groups having greater durability (Jones and Libicki, 2008). The measure for the size of the terrorist group, Size, is a simple ordinal variable coded 1 if the size of the group was less than 100 people, 2 if the group's size was $100-999$ people, 3 if the group numbered 1000-9999, and 4 if the group's size was 10,000 or more individuals. $^{23}$

Second, previous literature also identifies terrorist groups' ideological views as a significant factor affecting group longevity, with nationalist and religious terrorist organizations being more durable than leftist and right-wing groups. We separate the ideology measures from Jones and Libicki (2008) into four dummy variables. Dummies are created for nationalist terrorist groups, religious groups, leftist groups and right-wing groups. Nationalist groups were most represented in our sample, representing $38.2 \%$ of cases, followed by leftist groups with $33.4 \%$, religious groups with $23.2 \%$, and right-wing groups only representing $5 \%$ of all cases. In

\footnotetext{
${ }^{22}$ One might object that findings based on this interaction are the result of a small number of cases since repression and democracy likely co-vary. While we do not dispute that democracies, on average, have lower levels of repression than non-democratic regimes, the literature review mentions numerous case studies documenting the use of coercive strategies in democracies. Moreover, a cross-tabulation of the Repression and Polity variables showed that $30 \%$ of all democracies with polity scores of 6 or greater score 4 or higher on the repression variable. When only highly democratic countries (polity scores of 8 or greater) are included, the percentage of democracies engaging in such levels of repression decreases to $26 \%$. The literature on repression and democracy suggests that democracies exhibit lower levels of repression only when high levels of democracy are reached, but one-fourth of highly democratic states in our data apply high levels of repression (Davenport and Armstrong, 2004). Conversely, $13 \%$ of non-democratic regimes have repression levels lower than 3 . We also constructed models with a democracy dummy variable coded 1 for polity scores of 8 and higher, but results were virtually identical to the model including a democracy dummy coded 1 for scores greater than 6 .

${ }^{23}$ It is important to note that this variable does not change over time, meaning that it cannot account for variations in a group's size over its life cycle. While it would be ideal to use a time-varying covariate, no such data are available.
} 
our models, right-wing groups are the excluded category because they were least represented in the data (Long and Freese, 2006).

Third, we control for the breadth of terrorist goals, which has been considered in previous literature without conclusive results (Jones and Libicki, 2008). This measure is coded as an ordinal variable, Goal breadth. The variable is coded according to the scope of each group's vision for change. It ranges from 1-6, where lower values indicate that the group's goals are more narrowly focused, and greater values represent more broadly focused goals. Groups are coded as 1 if their goal is to maintain the status quo, 2 if their goal is policy change, 3 if their primary goal is regime change, 4 if their goal is territorial change, 5 if their goal is revolution, and 6 if their goal is empire.

A fourth control variable incorporates information on the number of countries in which individual terrorist organizations operate or have bases of support. Foreign presence, the last group characteristic variable, is a dummy variable that is coded 0 if the terrorist group is present in only one state and 1 if the group is present in two or more states.

Two additional control variables account for state characteristics aside from the repression and democracy measures. Economic development has been found by some studies to have no significant relationship with terrorist group termination, but in other studies it has shown a positive relationship. GDP per capita serves as our measure of state economic development. The GDP per capita measure was gathered from the Penn World Tables and is real GDP per capita in 2005 international dollars, which are U.S. dollars present in foreign economies (Heston et al., 2009). ${ }^{24}$ The measure therefore records the worth of a U.S. dollar, based on the goods it can purchase in each country's market. The natural log was taken because of high skewness in the data.

${ }^{24}$ Data available at http://pwt.econ.upenn.edu/php_site/pwt index.php. 
Population, a measure accounting for country size, was gathered from the World Bank's World Development Indicators. ${ }^{25}$ The literature has commonly used population as a control for the size of a country, and we include it in our models. The variable was logged in order to achieve a normal distribution.

\section{Methodology}

We use a Cox proportional hazards model to estimate group termination. Cox models have been used to predict event failure in other studies of international and domestic conflict (see Cunningham et al., 2009 for a recent example in predicting termination of civil war conflict). The model allows us to estimate the hazard function predicting the failure or termination of conflict within a particular time interval. ${ }^{26}$ The hazard rate for any observation $i$ at a particular point in time $t$ is given by the function $h_{i}(t)=h_{0}(t) \exp \left(x_{t}^{\prime} \beta\right)$ with $h_{0}(t)$ as the baseline hazard of the event. In this type of model, hazard rates are only calculated as failures and are not sensitive to issues of distribution because the baseline hazard rate cancels out when the hazard ratio is taken in the event of a failure. In the following tables, the hazard ratio is a covariate's effect on the baseline hazard. Hazard ratios smaller than 1 indicate that an independent variable increases the hazard of a terrorist group terminating within a specified time interval, and ratios less than 1

\footnotetext{
${ }^{25}$ Data are available at http://publications.worldbank.org/WDI/.

${ }^{26}$ One restriction imposed on the Cox regression model is the assumption of proportionality, meaning that the effect of the covariates on the hazard ratio has to be proportional over the lifespan of a terrorist group. We conducted tests of the proportional hazards assumption for models presented in table 2. Results for a test based on Schoenfeld residuals indicated no evidence for non-proportionality for key independent variables, but showed a violation of the proportionality assumption for the group size variable. A common strategy to deal with time-varying covariates is to interact such variables with time. Keele (2010), however, points out that the test to detect non-proportionality depends on correct model specification, meaning that a failure to specify the correct functional form of a covariate can result in positive test results. We follow Keele's (2010: 195) suggestion to include spline variables for such covariates as a way to model nonlinearity. We find that non-proportionality disappears once splines for the group size variable are included. Models presented in table 2 include spline variables for the group size variable. Hazard ratios for splines are not reported to conserve space.
} 
mean that an independent variable decreases the hazard rate of terrorist group termination. All models employ robust standard errors. ${ }^{27}$

\section{Results}

The first column in table 2 reports the model estimating democracy and repression with additional controls for state and group characteristics. In this model, findings for Polity mirror past studies where no significant relationship was found between this indicator and terrorist group termination. The hazard ratio for Polity is negative but not significant. Similarly, the hazard ratio for Repression is negative but insignificant. Existing large-N studies have not included a measure for repression, and our findings suggest that repression does not affect group termination independently.

\section{TABLE 2 ABOUT HERE}

Only controls for other state and group characteristics are significant in the first model. Population is negative and significant $(z=-3.26)$ indicating that the larger the population of any particular country, the less likely it is that terrorist groups will terminate. In terms of substantive effects (presented in table 3), varying the population variable \pm 1 SD from the mean reduces the hazard of failure by $28 \%$. In addition, several variables measuring group characteristics are significant in this model. Size, measuring group size, is significant and negative, which indicates that larger groups are less likely to fail. ${ }^{28}$ Religious terrorist groups, represented by the Religious dummy, are less likely to terminate than right-wing terror groups (the excluded category).

\footnotetext{
${ }^{27}$ We also analyzed models with standard errors clustered on home country. Results are very similar to the ones presented here.

${ }^{28} \mathrm{We}$ also analyzed our results excluding the group size category for the largest groups, which are groups with more than 10,000 supporters. Some may argue that groups of such magnitude should be categorized as rebel or insurgent groups since they may not appropriately reflect the power asymmetries usually associated with terrorist organizations. Excluding these groups did not change our results.
} 
Similarly, nationalist groups, represented by the Nationalist dummy, are less likely to end their campaigns than right-wing organizations. The Goal Breadth variable also is significant and negative, indicating that the more expansive the terrorist group goals, the less likely the group will fail. The only other variables that do not reach significance beside the Leftist variable are the GDP per capita variable and the Foreign presence variable. These results indicate that level of economic development, leftist group ideology, and the presence of terrorist groups in multiple countries have no effect on the likelihood of terrorist group failure. Marginal effects for significant variables in all models are presented in table 3.

\section{TABLE 3 ABOUT HERE}

The second model in table 2 reports the estimates when Repression is interacted with Polity. The hazard ratio is significant and negative $(z=-2.48)$, indicating that repression is a counterproductive strategy in democracies because it decreases the risk of terrorist group termination. If the polity variable is set at 10 , the repression variable is varied $\pm 1 \mathrm{SD}$, and the interaction varied along with the respective values of Polity and Repression, the hazard of group termination decreases by $24 \%$. Conversely, repression increases the likelihood of terrorist group failure in non-democratic regimes. Setting the polity variable at -3 , varying the repression variable from $\pm 1 \mathrm{SD}$ from the mean, and varying the interaction along with the respective values of Polity and Repression produces a $84 \%$ increase in the risk of termination, the strongest substantive effect in the model. This finding thus supports hypotheses 1 and 2, which expected that the effect of repression varies with regime type.

\section{FIGURE 1 ABOUT HERE}

Since interaction effects are difficult to interpret by evaluating hazard ratios alone, figure 1 provides further illustration of the conditional relationship between repression and democracy. 
Figure 1 demonstrates the effect of repression on the likelihood of failure in democratic and nondemocratic states. In this figure, the first graph presents the effect of repression on group termination when Polity is set at $10(+1 \mathrm{SD}$ from the mean) and the second graph presents the same effect when Polity is set at -3 (-1SD from the mean). In both graphs, Repression is varied from 1.5 to 4.5 ( \pm 1 standard deviation from the mean), and the interaction is varied along with the respective values of Repression and Polity. The first graph in figure 1 presents the effect of repression on group termination in democratic states. High repression in democracies, as represented by the dotted line, results in lower rates of termination than low levels of repression, as represented by the solid trend line. These results suggest that democracies may hamper their ability to counter and terminate terrorist organizations by applying more repressive policies. The opposite effect is observed in the second graph shown in figure 1. For non-democracies, higher repression, as illustrated by the dotted line, leads to substantially higher cumulative hazard ratios and therefore a greater likelihood of terrorist group termination over time than low repression, represented by the solid line. This suggests that non-democracies may hasten the failure of terrorist organizations by instituting more repressive policies. Taken together, results presented in model 2 and illustrated in the figure strongly support our theoretical expectations.

Table 2 presents a number of additional models that evaluate whether these findings are robust to alternative model specifications. The third model in table 2 examines whether findings are similar for the 1998-2006 period. As mentioned above, the RAND-MIPT data used to create the list of terrorist groups in Jones and Libicki (2008) includes domestic terrorist incidents only for the post-1998 period. Findings confirm the conditional relationship between democracy and repression for this subset of the data. The interaction is negative and weakly significant ( $z=-$ 1.84), confirming that repression is counterproductive in democracies. While the significance 
level for this finding is arguably weaker, we observe the same effect for other control variables in the model.

The fourth model in table 2 excludes splinter groups from the analysis. Since such groups may continue their engagement in terrorism, coding such groups as terminated is potentially problematic. We find that our results do not change when such groups are excluded, as exhibited in the negative and significant interaction term between Polity and Repression ( $z=-2.24)$. The next model in table 2 measures democracy dichotomously rather than the continuous measure employed in other models. Democracy is a dummy variable coded 0 if the country's Polity score is +5 or lower and 1 if the Polity score is +6 or higher. Results show that the relationship between repression and democracy holds for this alternative variable specification. The interaction between the democracy dummy and repression is negative and significant $(z=-2.40)$, again confirming that repression increases the duration of terrorist organizations in democracies.

The final model in table 2 employs an alternative measure of repression. It may be that not all types of repression matter equally when evaluating the effect of repression and regime type on terrorist group termination. In particular, our argument suggests that repressive measures reducing citizens' cooperation with authorities are particularly likely to benefit terrorist group recruitment and duration. Democratic governments showing little respect for physical integrity rights by engaging in disappearances, extrajudicial killings, holding political prisoners, or torture may be particularly likely to suffer from popular backlash. We use data from Cingranelli and Richards' Human Rights dataset to account for the effect of respect for physical integrity rights on terrorist group termination (Cingranelli and Richards, 2004). ${ }^{29}$ The Physical Integrity variable includes four physical integrity rights: disappearances, extrajudicial killings, holding political prisoners, and torture. This index ranges from least respectful (0) to most respectful (8). Results

\footnotetext{
${ }^{29}$ The index is available from 1981 forward, which explains the smaller number of cases in this model.
} 
for this model show that the interaction between Physical Integrity and Polity is positive and weakly significant $(z=1.74)$. While the hazard ratio of the interaction term is in the opposite direction of previous models, it is a function of the inverse coding of the physical integrity measure. The result thus suggests that terrorist groups in democratic states with respect for physical integrity rights are more likely to end their campaigns, confirming the relationship presented in earlier models. Results for control variables are very similar to the first two models, showing that group size, population size, religious and nationalist ideology, and goal breadth all increase the lifespan of terrorist organizations.

\section{Conclusion}

In this paper, we set out to identify important group and state characteristics that help explain the termination of terrorist organizations. A statistical analysis including a variety of group and state-level characteristics for 597 terrorist groups in the 1976-2006 period demonstrates how a number of factors impact decisions to end terrorism. With regard to groups, larger groups and groups with more extensive goals are less likely to end their campaigns. Moreover, groups with religious and nationalist ideologies are less likely to terminate than organizations pursuing other ideological goals. With regard to state characteristics, results on population size consistently show how states with larger populations have greater difficulty in eliminating terrorist organizations.

In addition, we argued in the theoretical section that the use of repression, a state response to terrorism, has different effects on group termination depending on countries' regime type. In democracies, coercive tactics can have counterproductive effects by altering citizens' perception of the legitimacy of the regime. Coercive government responses in democracies 
reduce the public's cooperation with government authorities and increase support for terrorist groups. A different dynamic is expected in non-democratic regimes. Since repression is often commonplace in these regimes, it is not likely to change the perceived legitimacy of the government, and a backlash against the state in the form of increased support for terrorist groups is unlikely. Our empirical results confirm these expectations, and these findings are robust to a number of alternative model specifications.

This research has interesting implications for terrorism researchers and policymakers. First, the argument helps understand the lack of consistent empirical findings on the relationship between regime type and terrorist group duration. Past studies have primarily investigated whether democracy has a direct effect on termination, yet the evidence presented here suggests that democracy's effect will be contingent on state repression. Second, the paper raises difficult issues for U.S. foreign policy. U.S. foreign policy makers simultaneously champion the promotion of democracy abroad and the global fight against terrorism. While our findings confirm that repression can be useful in achieving the latter goal, it will certainly not contribute to establishing the foundations for democracy. Thus, extensive aid for counterterrorism operations in countries such as Pakistan will likely undermine other long-term goals of U.S. foreign policy. There are additional reasons to expect that the use of iron-fist strategies will not be without negative consequences, especially in the long run. First, repression may succeed in eliminating a terrorist group in the affected country, but can create an exodus into other states. For example, Islamist groups in Uzbekistan infiltrated surrounding states after heavy repression by the authoritarian leadership (Omelicheva, 2007). Similarly, Chechen rebels fled to surrounding republics after the hard-line strategy of the Russian government (Evangelista, 2002: 189; Cronin, 2009: 63). Second, it is questionable whether repression can be successful as a 
long-term strategy and may not lead to the renewed eruption of violence. Interestingly, Rashwan's (2009) study of the Egyptian government's response suggests that an important aspect of its success was a more conciliatory stance toward al-Jama`a once the group renounced its violent struggle. It is likely, however, that governments switching from hard-line to accommodative policies face serious credibility problems. 
Table 1: Summary Statistics for Dependent and Independent Variables

\begin{tabular}{|c|c|c|c|c|}
\hline Variables & Mean & SD & Description & Source \\
\hline Termination & 0 & - & $=1$ in year of group termination & Jones and Libicki (2008) \\
\hline Repression & 3.15 & 1.23 & $\begin{array}{l}\text { Level of state repression, ranging from } \\
\text { least repressive (1) to most repressive (5) }\end{array}$ & Political Terror Scale (PTS) \\
\hline Polity & 3.57 & 6.94 & $\begin{array}{l}\text { Polity score, ranging from least democratic } \\
(-10) \text { to most democratic }(+10)\end{array}$ & Polity IV data \\
\hline Democracy & 1 & - & $=1$ if polity score $>5$ & Polity IV data \\
\hline Physical Integrity & 3.29 & 2.60 & $\begin{array}{l}\text { Respect for physical integrity rights, } \\
\text { ranging from least respect (0) to most ( } 8 \text { ) }\end{array}$ & $\begin{array}{l}\text { Cingranelli and Richards } \\
\text { (CIRI) Human Rights data }\end{array}$ \\
\hline GDP per capita (log) & 8.67 & 1.09 & GDP per capita, annual statistics & Penn World Tables (PWT) \\
\hline Population (log) & 17.71 & 1.97 & Population size, annual statistics & $\begin{array}{l}\text { World Development } \\
\text { Indicators (WDI) }\end{array}$ \\
\hline Size & 2.17 & 0.95 & $\begin{array}{l}\text { Terrorist group size, ranging from smallest } \\
\text { (less than } 100) \text { to largest }(10,000 \text { or more) }\end{array}$ & Jones and Libicki (2008) \\
\hline Leftist & 0 & - & $=1$ for terrorist group with leftist ideology & Jones and Libicki (2008) \\
\hline Religious & 0 & - & $\begin{array}{l}=1 \text { for terrorist group with religious } \\
\text { ideology }\end{array}$ & Jones and Libicki (2008) \\
\hline Nationalist & 0 & - & $\begin{array}{l}=1 \text { for terrorist group with nationalist } \\
\text { ideology }\end{array}$ & Jones and Libicki (2008) \\
\hline Goal breadth & 3.54 & 1.12 & $\begin{array}{l}\text { Scope of group goals, ranging from } \\
\text { narrowest (status quo) to broadest (empire) }\end{array}$ & Jones and Libicki (2008) \\
\hline Foreign presence & 0 & - & $\begin{array}{l}=1 \text { if terrorist group has presence in more } \\
\text { than one state }\end{array}$ & Jones and Libicki (2008) \\
\hline
\end{tabular}

Note: Means are presented for continuous variables, modes for dichotomous variables. 
Table 2: The Determinants of Terrorist Group Termination

\begin{tabular}{|c|c|c|c|c|c|c|}
\hline Variables & Base Model & $\begin{array}{l}\text { Base Model with } \\
\text { Interaction }\end{array}$ & Years 1998-2006 & $\begin{array}{l}\text { Excluding } \\
\text { Splinter Groups }\end{array}$ & $\begin{array}{l}\text { Democracy } \\
\text { Dummy }\end{array}$ & $\begin{array}{l}\text { Physical Integrity } \\
\text { Rights }\end{array}$ \\
\hline & $\begin{array}{l}\text { Hazard Ratio } \\
\text { (S.E.) }\end{array}$ & $\begin{array}{l}\text { Hazard Ratio } \\
\text { (S.E.) }\end{array}$ & $\begin{array}{l}\text { Hazard Ratio } \\
\text { (S.E.) }\end{array}$ & $\begin{array}{l}\text { Hazard Ratio } \\
\text { (S.E.) }\end{array}$ & $\begin{array}{l}\text { Hazard Ratio } \\
\text { (S.E.) }\end{array}$ & $\begin{array}{l}\text { Hazard Ratio } \\
\text { (S.E.) }\end{array}$ \\
\hline Repression & $\begin{array}{l}0.992 \\
(0.050)\end{array}$ & $\begin{array}{l}1.145^{*} \\
(0.090)\end{array}$ & $\begin{array}{l}1.286 \\
(0.342)\end{array}$ & $\begin{array}{l}1.083 \\
(0.109)\end{array}$ & $\begin{array}{l}1.306 * * \\
(0.164)\end{array}$ & - \\
\hline Polity & $\begin{array}{l}0.989 \\
(0.010)\end{array}$ & $\begin{array}{l}1.073 * * \\
(0.038)\end{array}$ & $\begin{array}{l}1.125 \\
(0.112)\end{array}$ & $\begin{array}{c}1.090 * \\
(0.050)\end{array}$ & - & $\begin{array}{l}0.963 * * \\
(0.014)\end{array}$ \\
\hline Repression x Polity & - & $\begin{array}{l}0.977 * * \\
(0.009)\end{array}$ & $\begin{array}{l}0.952 * \\
(0.027)\end{array}$ & $\begin{array}{l}0.974 * * \\
(0.012)\end{array}$ & - & - \\
\hline Democracy & - & - & , & - & $\begin{array}{l}2.841 * * \\
(1.521)\end{array}$ & - \\
\hline Repression x Democracy & - & - & - & - & $\begin{array}{l}0.710 * * \\
(0.101)\end{array}$ & - \\
\hline Physical Integrity & - & - & - & - & - & $\begin{array}{l}0.991 \\
(0.034)\end{array}$ \\
\hline Physical Integrity x Polity & - & - & - & - & - & $\begin{array}{l}1.007 * \\
(0.004)\end{array}$ \\
\hline GDP per capita (log) & $\begin{array}{l}1.068 \\
(0.079)\end{array}$ & $\begin{array}{l}1.010 \\
(0.077)\end{array}$ & $\begin{array}{l}1.017 \\
(0.129)\end{array}$ & $\begin{array}{l}0.980 \\
(0.089)\end{array}$ & $\begin{array}{l}1.025 \\
(0.075)\end{array}$ & $\begin{array}{l}1.035 \\
(0.085)\end{array}$ \\
\hline Population (log) & $\begin{array}{l}0.920 * * * \\
(0.026)\end{array}$ & $\begin{array}{l}0.913^{* * * *} \\
(0.026)\end{array}$ & $\begin{array}{l}0.930 \\
(0.053)\end{array}$ & $\begin{array}{l}0.887 * * * \\
(0.035)\end{array}$ & $\begin{array}{l}0.916 * * * \\
(0.026)\end{array}$ & $\begin{array}{l}0.924 * * * \\
(0.027)\end{array}$ \\
\hline Size & $\begin{array}{l}0.528 * * * \\
(0.044)\end{array}$ & $\begin{array}{l}0.531 * * * \\
(0.044)\end{array}$ & $\begin{array}{l}0.745 * \\
(0.123)\end{array}$ & $\begin{array}{l}0.614 * * * \\
(0.059)\end{array}$ & $\begin{array}{l}0.527 * * * \\
(0.044)\end{array}$ & $\begin{array}{l}0.546 * * * \\
(0.048)\end{array}$ \\
\hline Leftist & $\begin{array}{l}0.839 \\
(0.144)\end{array}$ & $\begin{array}{l}0.838 \\
(0.143)\end{array}$ & $\begin{array}{l}0.909 \\
(0.336)\end{array}$ & $\begin{array}{l}0.710^{*} \\
(0.141)\end{array}$ & $\begin{array}{l}0.838 \\
(0.143)\end{array}$ & $\begin{array}{c}0.901 \\
(0.164)\end{array}$ \\
\hline Religious & $\begin{array}{l}0.370 * * * \\
(0.094)\end{array}$ & $\begin{array}{l}0.392 * * * \\
(0.098)\end{array}$ & $\begin{array}{l}0.323 * * \\
(0.148)\end{array}$ & $\begin{array}{l}0.227 * * * \\
(0.076)\end{array}$ & $\begin{array}{l}0.394 * * * \\
(0.099)\end{array}$ & $\begin{array}{l}0.427 * * * \\
(0.110)\end{array}$ \\
\hline Nationalist & $\begin{array}{l}0.722 * \\
(0.127)\end{array}$ & $\begin{array}{l}0.742 * \\
(0.129)\end{array}$ & $\begin{array}{l}0.766 \\
(0.288)\end{array}$ & $\begin{array}{l}0.534 * * * \\
(0.114)\end{array}$ & $\begin{array}{l}0.739 * \\
(0.129)\end{array}$ & $\begin{array}{c}0.804 \\
(0.152)\end{array}$ \\
\hline Goal breadth & $\begin{array}{l}0.914 * * \\
(0.036)\end{array}$ & $\begin{array}{l}0.914 * * \\
(0.036)\end{array}$ & $\begin{array}{l}0.883 * \\
(0.062)\end{array}$ & $\begin{array}{l}0.846^{* * *} * \\
(0.047)\end{array}$ & $\begin{array}{l}0.914 * * \\
(0.036)\end{array}$ & $\begin{array}{l}0.912 * * \\
(0.035)\end{array}$ \\
\hline Foreign presence & $\begin{array}{l}0.936 \\
(0.147) \\
\end{array}$ & $\begin{array}{l}0.911 \\
(0.144) \\
\end{array}$ & $\begin{array}{l}1.124 \\
(0.304) \\
\end{array}$ & $\begin{array}{c}0.925 \\
(0.186) \\
\end{array}$ & $\begin{array}{l}0.922 \\
(0.144) \\
\end{array}$ & $\begin{array}{l}0.941 \\
(0.149) \\
\end{array}$ \\
\hline$N$ & 5,116 & 5,116 & 1,522 & 5,010 & 5,116 & 4,466 \\
\hline Wald $\chi^{2}$ & 122.97 & 132.92 & 35.62 & 108.04 & 133.90 & 115.78 \\
\hline
\end{tabular}

*** significant at $p<0.01$; ** significant at $p<0.05$; $*$ significant at $p<0.1$ 


\section{Figure 1: The Effect of Repression on Terrorist Group Duration}
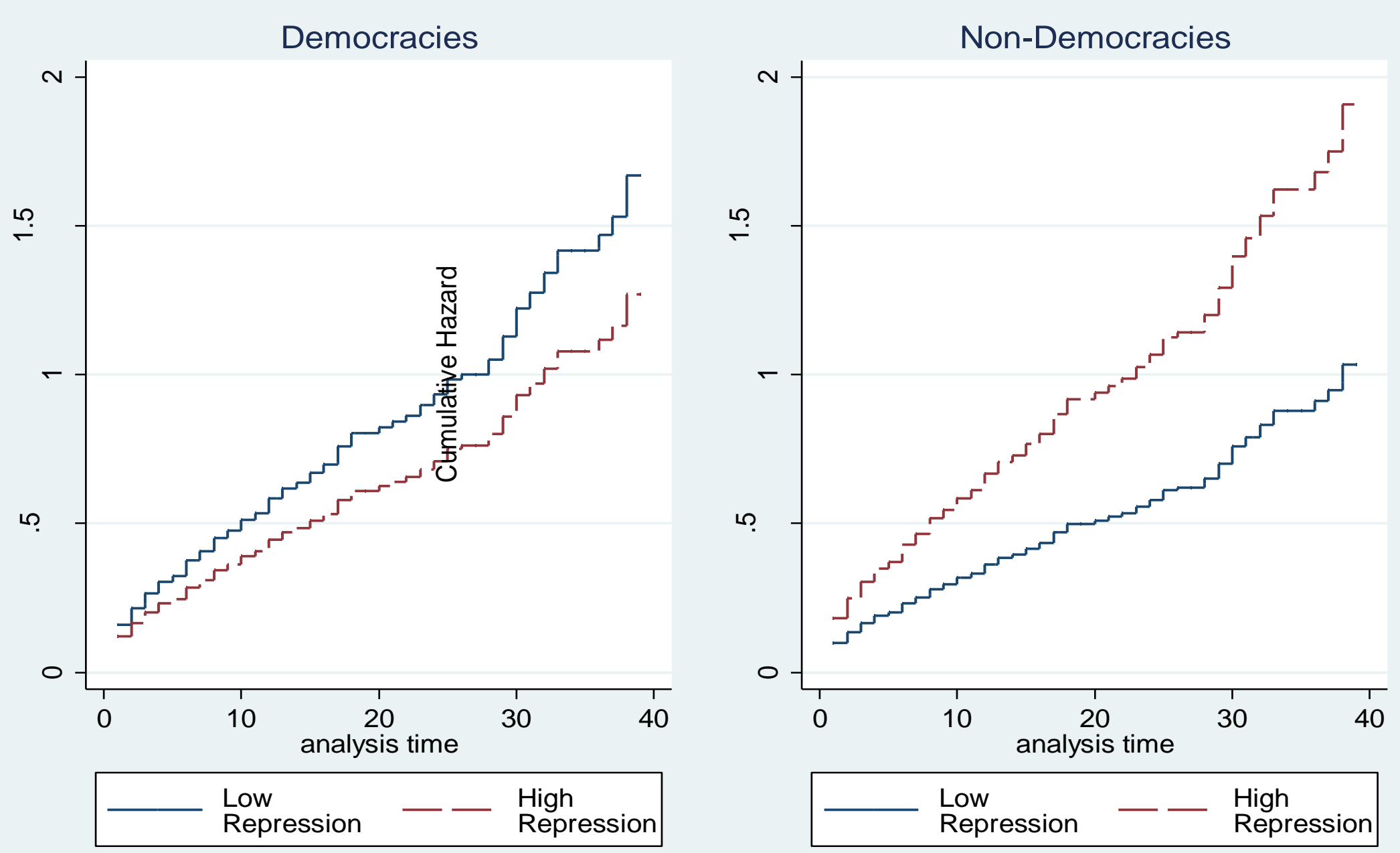
Table 3: The Determinants of Terrorist Group Termination, Substantive Effects

\begin{tabular}{|c|c|c|}
\hline Variables & Base Model & $\begin{array}{l}\text { Base Model with } \\
\text { Interaction }\end{array}$ \\
\hline & Change in Hazard (\% $\%$ ) & Change in Hazard (\% $\%$ ) \\
\hline $\begin{array}{c}\text { Repression in Democracies }^{\mathrm{a}} \\
1.5(-1 \mathrm{SD}) \\
4.5(+1 \mathrm{SD})\end{array}$ & ( & $\begin{array}{l}0.047 \\
0.036(-23.9)\end{array}$ \\
\hline $\begin{array}{c}\text { Repression in Non-Democracies }{ }^{\mathrm{b}} \\
1.5(-1 \mathrm{SD}) \\
4.5(+1 \mathrm{SD})\end{array}$ & - & $\begin{array}{l}0.029 \\
0.054(+84.3)\end{array}$ \\
\hline $\begin{array}{l}\text { Population (log) } \\
15.7(-1 \mathrm{SD}) \\
19.7(+1 \mathrm{SD})\end{array}$ & $\begin{array}{l}0.054 \\
0.039(-27.9)\end{array}$ & $\begin{array}{l}0.053 \\
0.037(-30.1)\end{array}$ \\
\hline $\begin{array}{l}\text { Size } \\
\qquad \begin{array}{l}1(-1 \mathrm{SD}) \\
3(+1 \mathrm{SD})\end{array}\end{array}$ & $\begin{array}{l}0.094 \\
0.026(-72.1)\end{array}$ & $\begin{array}{l}0.090 \\
0.025(-71.8)\end{array}$ \\
\hline $\begin{array}{l}\text { Religious group } \\
0 \text { (min) } \\
1(\max )\end{array}$ & $\begin{array}{l}0.056 \\
0.021(-63.0)\end{array}$ & $\begin{array}{l}0.053 \\
0.021(-60.8)\end{array}$ \\
\hline $\begin{array}{l}\text { Nationalist group } \\
0 \text { (min) } \\
1(\max )\end{array}$ & $\begin{array}{l}0.051 \\
0.037(-27.8)\end{array}$ & $\begin{array}{l}0.048 \\
0.036(-25.8)\end{array}$ \\
\hline $\begin{array}{l}\text { Goal breadth } \\
\qquad \begin{array}{l}2(-1 \mathrm{SD}) \\
5(+1 \mathrm{SD})\end{array}\end{array}$ & $\begin{array}{l}0.052 \\
0.040(-23.7)\end{array}$ & $\begin{array}{l}0.050 \\
0.038(-23.7)\end{array}$ \\
\hline
\end{tabular}




\section{References}

Abadie, Alberto. 2006. "Poverty, Political Freedom, and the Roots of Terrorism." American Economic Review 96: $50-56$.

Abrahms, Max. 2007. Why Democracies Make Superior Counterterrorists. Security Studies 16: 223-253.

Blomberg, S. Brock, Rozlyn C. Engel, and Reid Sawyer. 2009. "On the Duration and Sustainability of Transnational Terrorist Organizations.” Forthcoming in Journal of Conflict Resolution.

Bueno de Mesquita, Ethan. 2005. “The Quality of Terror.” American Journal of Political Science 49(3): 515-530.

Bueno de Mesquita, Ethan and Eric S. Dickson. 2007. "The Propaganda of the Deed: Terrorism, Counterterrorism, and Mobilization." American Journal of Political Science 51(2): 364-381.

Cingranelli, David L. and David L. Richards. 2004. The Cingranelli-Richards (CIRI) Human Rights Dataset. Retrieved January 21, 2011 from http://ciri.binghamton.edu/

Crenshaw, Martha. 1991. "How Terrorism Declines.” Terrorism and Political Violence 3(1): 69-87.

Cronin, Audrey Kurth. 2006. "How Al Qaida Ends: The Decline and Demise of Terrorist Groups." International Security 31(1): 7-48.

Cronin, Audrey Kurth. 2009. "How Terrorist Campaigns End.” In Tore Bjorgo and John Horgan (eds.) Leaving Terrorism Behind: Individual and Collective Disengagement. New York, NY: Routledge, pp. 49-66.

Cunningham, David E., Kristian Skrede Gleditsch and Idean Salehyan. 2009. "It Takes Two: A Dyadic Analysis of Civil War Duration and Outcome.” Journal of Conflict Resolution 53(4): 570-597.

Davenport, Christian. 2007. "State Repression and Political Order.” Annual Review of Political Science 10: 1-23.

Davenport, Christian and David A. Armstrong. 2004. "Democracy and the Violation of Human Rights." American Journal of Political Science 48: 538-554.

Della Porta, Donatella. 2009. "Leaving Underground Organizations: A Sociological Analysis of the Italian Case.” In Tore Bjorgo and John Horgan (eds) Leaving Terrorism Behind: Individual and Collective Disengagement New York, NY: Routledge, pp. 66-88.

Donohue, Laura K. 2008. The Cost of Counterterrorism: Power, Politics, and Liberty. Cambridge: Cambridge University Press.

Eubank, William Lee and Leonard Weinberg. 1994. "Does Democracy Encourage Terrorism?" Terrorism and Political Violence 6(4): 108-118.

Evangelista, Matthew. 2002. The Chechen Wars: Will Russia Go the Way of the Soviet Union? Washington, DC: Brookings Institution Press.

Fearon, James D. and David D. Laitin. 2003. "Ethnicity, Insurgency, and Civil War." American Political Science Review 97(1): 75-90.

Francisco, Ronald A. 1995. "The Relationship between Coercion and Protest: An Empirical Evaluation in Three Coercive States.” Journal of Conflict Resolution 39: 263-82.

Gerges, Fawaz A. 2000. “The End of the Islamist Insurgency in Egypt? Costs and Prospects.” Middle East Journal 54(4): 592-612. 
Gibney, Mark, L. Cornett and Reed Wood. 2008. Political Terror Scale 1976-2006. Retrieved January 21, 2010, from http://www.politicalterrorscale.org/.

Guelke, Adrian. 2007. "The Northern Ireland Peace Process and the War Against Terrorism: Conflicting Conceptions?" Government and Opposition 42(3): 272-291.

Gurr, Ted Robert. 1971. Why Men Rebel. Princeton, NJ: Princeton University Press.

Gurr, Ted Robert and Will H. Moore. 1997. "Ethnopolitical Rebellion: A Cross-Sectional Analysis of the 1980s with Risk Assessments for the 1990s." American Journal of Political Science 41: 1079-1103.

Handelman, Howard. 1981. "Labor-Industrial Conflict and the Collapse of Uruguayan Democracy." Journal of Interamerican Studies and World Affairs 23(4): 371-394.

Heston, Alan, Robert Summers and Bettina Aten. 2009. Penn World Table Version 6.3. Center for International Comparisons of Production, Income and Prices at the University of Pennsylvania. Retrieved January 21, 2010 from http://pwt.econ.upenn.edu/

Hibbs, Douglas A. (1973). Mass Political Violence: A Cross-national Causal Analysis. New York: John Wiley.

Hoffman, Bruce. 2006. Inside Terrorism. New York, NY: Columbia University Press.

Iqbal, Zaryab and Christopher Zorn. 2006. "Sic Semper Tyrannis? Power, Repression, and Assassination Since the Second World War.” Journal of Politics 68(3): 489-501.

Keele, Luke. 2010. "Proportionally Difficult. Testing for Non-Proportional Hazards in Cox Models." Political Analysis 18:189-205.

Kurrild-Klitgaard, Peter, Mogens Justesen, and Robert Klemmensen. 2006. "The Political Economy of Freedom, Democracy and Transnational Terrorism.” Public Choice 128: 289-315.

Kydd, Andrew L. and Barbara F. Walter. 2006. “The Strategies of Terrorism.” International Security 31(1): 49-79.

Jones, Seth G and Martin C. Libicki. 2008. How Terrorist Groups End: Lessons for Countering Al-Qaida. Santa Monica: Rand Corporation.

LaFree, Gary and Gary Ackerman. 2009. “The Empirical Study of Terrorism: Social and Legal Research,” Annual Review of Law and Social Science 5: 347-74.

LaFree, Gary, Laura Dugan, and Raven Korte. 2009. "The Impact of British Counterterrorist Strategies on Political Violence in Northern Ireland: Comparing Deterrence and Backlash Models," Criminology 47(1): 17-45.

Lewis, Paul H. 2006. Authoritarian Regimes in Latin America: Dictators, Despots, and Tyrants. Oxford, UK: Rowman \& Littlefield.

Lichbach, Mark I. 1987. "Deterrence or Escalation? The Puzzle of Aggregate Studies of Repression or Dissent." Journal of Conflict Resolution 31(2): 266-297.

Long, Scott and Jeremy Freese. 2006. Regression Models for Categorical Dependent Variables Using Stata, $2^{\text {nd }}$ edition. College Station, Texas: Stata Press.

Marshall, Monty G. and Keith Jaggers. 2009. Polity IV Project: Political Regime Characteristics and Transitions, 1800-2007. Center for Systemic Peace. Retrieved January 21, 2010 from http://www.systemicpeace.org/

Mason, T. David and Dale A. Krane. 1989. "The Political Economy of Death Squads: Toward a Theory of the Impact of State-Sanctioned Terror.” International Studies Quarterly 33( 2): 175-98. 
Moore, Will H. 1998. "Repression and Dissent: Substitution, Context, and Timing." American Journal of Political Science 42(3): 851-873.

Muller, Edward M. 1985. "Income Inequality, Regime Repressiveness, and Political Violence." American Sociological Review 5 (February): 47 -61.

Omelicheva, Mariya Y. 2007. "Combating Terrorism in Central Asia: Explaining Differences in States' Responses to Terror." Terrorism and Political Violence 19: 369-393.

Pape, Robert A. 2005. Dying to Win: The Strategic Logic of Suicide Terrorism. Random House.

Parker, Tom. 2007. "Fighting an Antaean Enemy: How Democratic States Unintentionally Sustain the Terrorist Movements They Oppose." Terrorism and Political Violence 19: 155-79.

Posner, Richard. 2007. Countering Terrorism: Blurred Focus, Halting Steps. Lanham, MD: Rowman \& Littlefield.

Rashwan, Diaa. 2009. “ The Renunciation of Violence by Egyptian Jihadi Organizations.” In Tore Bjorgo and John Horgan (eds) Leaving Terrorism Behind: Individual and Collective Disengagement New York, NY: Routledge, pp. 113-133.

Robisonet, Kristopher K., Edward M. Crenshaw and J. Craig Jenkins. 2006. "Ideologies of Violence: The Social Origins of Islamist and Leftist Transnational Terrorism.” Social Forces 84(4): 2009-2026.

Rosendorff, B. Peter and Todd Sandler. 2004. "Too Much of A Good Thing? The Proactive Response Dilemma." Journal of Conflict Resolution 48(5): 657-671.

Sanchez-Cuenca, Ignacio and Luis de la Calle. 2009. "Domestic Terrorism: The Hidden Side of Political Violence." Annual Review of Political Science (12): 31-49

Shabad, Goldie and Francisco José Llera Ramo. 1995. "Political Violence in a Democratic State: Basque Terrorism in Spain." In Martha Crenshaw (ed.) Terrorism in Context University Park, PA: The Pennsylvania State University Press.

Tankebe, Justice. 2009. "Public Cooperation With the Police in Ghana: Does Procedural Fairness Matter?" Criminology 47: 1265-93.

Testas, Abdelaziz. 2004. "Determinants of Terrorism in the Muslim World: An Empirical Cross-Sectional Analysis." Terrorism and Political Violence 16(2): 353-273.

Tilly, Charles. 2003. The Politics of Collective Violence. Cambridge, UK: Cambridge University Press.

Tyler, Tom R., Stephen Schulhofer, and Aziz Z. Huq. 2009. "Legitimacy and Deterrence Effects in Counterterrorism Policing: A Study of Muslim Americans." Law \& Society Review 44(2): 365-402.

Walsh, James I. and James A. Piazza. 2010. "Why Respecting Physical Integrity Rights Reduces Terrorism." Comparative Political Studies 43(5): 551-577.

White, Robert W. 1989. "From Peaceful Protest to Guerrilla War: Micromobilization of the Provisional Irish Republican Army." American Journal of Sociology 94:1277-1302.

World Bank. 2009. World Development Indicators. Retrieved January 21, 2010 from http://data.worldbank.org/datacatalog/world-development-indicators. 